\title{
Ruminal dry matter and fiber fraction degradability from two stylos cultivars
}

\author{
[Degradabilidade ruminal da matéria seca e fração fibrosa de \\ duas cultivares de estilosantes]
}

\author{
D.S. Corrêa, R.T. Magalhães, D.C.B. Siqueira
}

PUCGoiás - Goiânia, GO

\begin{abstract}
Ruminal degradability of dry matter, neutral detergent fiber and acid detergent fiber of cultivars Stylozanthes guianensis (Mineirão) and Stylozanthes spp. (Campo Grande) were evaluated. Two incubations in rumen-fistulated adult bovine females were undertaken. Each incubation comprised of 25 samples of $7.0 \mathrm{~g}$ of each cultivar and samples were collected at 0, 6, 9, 12, 24, 36, 48, 72 and 96 hours after incubation. At a 5\%/hour passage rate, Stylozanthes guianensis had 75.70, 59.01 and $76.81 \%$ effective degradability for dry matter, neutral detergent fiber and acid detergent fiber, respectively, whereas Stylozanthes spp. had 68.39, 51.93 and 58.89\% for the same fractions. The lag time was different $(\mathrm{P}<0.05)$ only for acid detergent fiber. Stylozanthes guianensis presented higher ruminal degradability in dry matter and fiber fraction when compared to those by Stylozanthes spp. The decision to adopt one or another cultivar depends on studies that take into account the cost of deployment and maintenance of leguminous cultivar and its assets.
\end{abstract}

Keywords: stylos, cattle breeding, tropical forage, ruminal degradability

\section{RESUMO}

Avaliou-se a degradabilidade ruminal da matéria e fração fibrosa do Stylozanthes guianensis $c v$. Mineirão e Stylozanthes spp. cv. Campo Grande. Foram realizadas duas incubações em fêmea bovina adulta canulada no rúmen. Em cada incubação foram utilizadas 25 amostras de cada cultivar (7,0 g). As amostras foram retiradas nos tempos 0, 6, 9, 12, 24, 36, 48, 72 e 96 horas de incubação. Para a taxa de passagem de 5\%/hora, o estilosantes Mineirão apresentou 75,70\%, 59,01\% e 76,81\% de degradabilidade efetiva (DE) da matéria seca (MS), fibra em detergente neutro (FDN) e fibra em detergente ácido (FDA), respectivamente, enquanto a cultivar Campo Grande alcançou DE de 68,39\% (MS), 51,93\% (FDN) e $58,89 \%$ (FDA). O tempo de colonização foi estatisticamente diferente $(P<0,05)$ apenas para a FDA. A cultivar Mineirão apresentou maior degradabilidade ruminal tanto para a MS quanto para a sua porção fibrosa. A escolha por uma das duas cultivares depende de estudos que levem em conta o custo de estabelecimento e manutenção das leguminosas e o benefício resultante.

Palavras-chave: bovinocultura, degradabilidade ruminal, estilosantes, forrageira tropical

\section{INTRODUCTION}

The Brazilian savannah comprises approximately $21 \%$ of the country's area. It is the second largest Brazilian biome (Aguiar et al., 2004) and one of the Earth's 25 hottest spots (Myers et al., 2000). Since around $26.5 \%$ of the biome is covered with pastures (Sano et al., 2008), the Brazilian savannah is the most important region for food

Recebido em 12 de fevereiro de 2013

Aceito em 16 de dezembro de 2013

E-mail: daniel.staciarini@terra.com.br production in Brazil and one of the world's leading food producing regions. Consequently, studies on food production in the biome are increasingly necessary and urgent.

The introduction of leguminous forage plants, characterized by their capacity to biologically fixate atmospheric nitrogen in the soil and thus improve diet (Paciullo et al., 2003; Silva and Saliba, 2007, Carvalho and Pires, 2008) and 
reducing nitrogen fertilizers, may be an alternative to increase animal production in the region.

The genus Stylosanthes belongs to the Fabaceae family with several subspecies and botanic varieties. It is native to South and Central America and most species are perennial, with a powerful root system and great colonization capacity (Barros et al., 2005). Stylosanthes are, as a rule, adapted to acid and low fertility soils, even though they show high responses to fertilizers. Plants are highly acceptable by animals and tolerant to manganese $(\mathrm{Mn})$ and aluminum (Al) toxicity (Silveira et al., 2005).

The cultivar Stylozanthes guianensis (mineirão) was commercially launched in 1993 by the Brazilian agricultural research company EMBRAPA. The cultivar is characterized by herbaceous sub-shrub size, semi-erect or erect growth, good adaptation to acid and low fertility soils, high leaf retention during the dry season, late flowering and resistance to anthracnose (Barcellos et al., 2008; Karia et al., 2010).

The Stylozanthes spp. (Campo Grande), launched in 2000, is composed of a mixture of seeds from the two varieties, $S$. capitata $(80 \%)$ and $S$. macrocephala $(20 \%)$ (Verzignassi \& Fernandes, 2002). Cultivar Campo Grande plants are well adapted to sandy soils, with good endurance under grazing, natural high seed production, low cost seeds and tolerance to anthracnose (Embrapa, 2007; Barcellos et al., 2008).

According to Brito et al. (2007), the in situ degradability technique has been improved, used and studied extensively during the last 25 years to better compare types of food and understand the fermentation process.

Current analysis evaluated the ruminal degradability of dry matter (DM), neutral detergent fiber (NDF) and acid detergent fiber (ADF) of Stylosanthes guianensis cv. Mineirão and Stylosanthes spp. cv. Campo Grande.

\section{MATERIALS AND METHODS}

The current study was conducted at the Department of Animal Science (Campus II) of the Pontifícia Universidade Católica de Goiás, Goiânia GO Brazil. Mineirão and Campo Grande cultivars were harvested respectively after 119 and 120 days of germination and pre-dried in a forced air oven at $65^{\circ} \mathrm{C}$ until constant weight. Part of the material was ground in a ThomasWilley mill with 1-mm sieves and stored in plastic containers for further chemical analysis. Another part of the material was ground in a 5-mm sieve for in situ assays.

Dry matter (DM) content was obtained by drying the material in a forced air oven at $65{ }^{\circ} \mathrm{C}$, followed by further drying at $105{ }^{\circ} \mathrm{C}$. Crude protein (CP) was determined by the Kjeldahl method (Association..., 1975) and neutral detergent fiber (NDF) and acid detergent fiber (ADF) were calculated by the sequential method (Robertson and Van Soest, 1981).

Ruminal degradability was determined by two inoculations, each with an adult cow (Holstein $\mathrm{x}$ Zebu), with ruminal fistula, penned in tie stall, with access to water and mineral mixture, and fed on corn silage ad libitum. Samples were all placed at the same time and removed at 0 (T0), 6 (T1), 9 (T2), 12 (T3), 24 (T4), 36 (T5), 48 (T6), 72 (T7) and 96 (T8) incubation hours.

Samples were placed in $5 \times 14 \mathrm{~cm}$-nylon bags with $50 \mu$ diameter pore size, sealed at the edges and identified. A total of 25 samples (with $7.0 \mathrm{~g}$ each) of each cultivar were used in each incubation. Samples from animals were washed in running water until the water was clean and then dried at $65^{\circ} \mathrm{C}$ until constant weight. DM, NDF and ADF degradability were determined.

Degradability equations followed the model by Orskov and McDonald (1979):

$\mathrm{Dg}=\mathrm{A}-\mathrm{B} \cdot e^{\mathrm{ct}}(1)$, where: $\mathrm{A}$ is maximum degradation rate of the material contained in a nylon bag; B is a parameter without biological value of interest. If there were no lag time, it would be equivalent to the total that would be degraded by microorganisms; $\mathrm{c}$ is the constant degradation rate of the fraction in the nylon bag and $t$ is the incubation time in the rumen.

After determining A, B and C parameters of the previous model, lag time was estimated according to McDonald (1981):

$\mathrm{LT}=-1 / \mathrm{c} . e(\mathrm{~A}-\mathrm{S}) / \mathrm{B}$, where: $\mathrm{A}, \mathrm{B}$ and $\mathrm{C}$ are the same parameters defined by equation (1) and $\mathrm{S}$ is the feed soluble fraction determined by the 
percentage removal at $t_{0}$ of incubation obtained by the samples' immersion in water.

Effective degradability (ED) was calculated following the model by Orskov and McDonald (1979):

$\mathrm{ED}=\mathrm{S}+(\mathrm{B}$. c $) /(\mathrm{c}+\mathrm{K})$, where: $\mathrm{K}$ is the fractional rate of the passage of small particles, obtained after the use of different levels of food and diet.

Lag time was calculated according to the model by McDonald (1981):

$\left(e \mathrm{RDP} \mathrm{t}_{0}-e \mathrm{RDP} \mathrm{t}\right) / \mathrm{c}$, where: eRDP $\mathrm{t}_{0}$ is the natural logarithm of the potentially degradable residue at time 0 ; eRDP $\mathrm{t}$ is the natural logarithm of the potentially degradable residue at final incubation time; $\mathrm{c}$ is the degradation rate of fraction B.

The experiment was conducted with a randomized block experiment design. Data were subjected to ANOVA and mean comparison test by Scott-Knot grouping tests at $5 \%$ probability.
Statistical analysis were performed with the SAS program (Statistical..., 1989).

\section{RESULTS AND DISCUSSION}

The results of chemical analysis (Table 1) for Mineirão presented higher $(\mathrm{P}<0.05)$ dry matter content and Campo Grande presented higher neutral detergent fiber and acid detergent fiber levels. Cultivars crude protein, organic matter and ash did not statistically differ $(\mathrm{P}>0.05)$.

Results of the chemical analysis (Table 1) showed that Stylosanthes guianensis cv. Mineirão had higher $(\mathrm{P}<0.05)$ dry matter rates, whereas Stylosanthes spp. cultivar Campo Grande presented higher neutral detergent fiber and acid detergent fiber levels. The cultivars' crude protein, organic matter and ash did not differ statistically ( $\mathrm{p}>0.05)$.

Protein levels were similar to those in Moura et al. (2011), which ranged between 18 to $24 \%$ for Stylosanthes spp. cultivar Campo Grande.

Table 1. Mean dry matter (DM), organic matter (OM), crude protein (CP), neutral detergent fiber (NDF), acid detergent fiber (ADF) and Ash rates of forage cultivars used in ruminal incubation

\begin{tabular}{lcc}
\cline { 3 - 3 } \multicolumn{1}{c}{ Item } & \multicolumn{2}{c}{ Forage } \\
\cline { 3 - 3 } & $\begin{array}{c}\text { Stylosanthes guianensis } \\
\text { cv. Mineirão }\end{array}$ & $\begin{array}{c}\text { Stylosanthes spp. } \\
\text { cv. Campo Grande }\end{array}$ \\
DM $(\%)$ & $28.20 \mathrm{~A}$ & $20.53 \mathrm{~B}$ \\
$\mathrm{CP}(\%$ of DM) $\mathrm{DM})$ & $90.50 \mathrm{~A}$ & $91.92 \mathrm{~A}$ \\
$\mathrm{NDF}(\%$ of DM) & $20.05 \mathrm{~A}$ & $19.92 \mathrm{~A}$ \\
$\mathrm{ADF}(\%$ of DM) & $45.93 \mathrm{~A}$ & $51.88 \mathrm{~B}$ \\
Ashes $(\%$ of DM) & $33.07 \mathrm{~A}$ & $40.24 \mathrm{~B}$ \\
\hline
\end{tabular}

${ }^{\mathrm{AB}}$ Values in the same row followed by different letters are different according to the Scott-Knot test $(\mathrm{P}<0.05)$

NDF level is related to intake capacity by animals, with high NDF levels inhibiting voluntary intake. In this work, both forages presented NDF level below that considered critical by Van Soest (1994), or rather, between $55 \%$ and $60 \%$ of DM.

High ADF percentage decreased forage quality and reduced its digestibility due to nutrients being bound to fiber and therefore hardly available to animals (Moura et al., 2011).

In the case of Stylosanthes guianensis cv. Mineirão, Valadares et al. (2002) reported 66.8\% for NDF and $32 \%$ for ADF. In the case of Stylosanthes spp. cv. Campo Grande, Moura et al. (2011) registered values ranging from $52 \%$ to $56 \%$ for NDF, depending on age and phosphorus fertilization levels, and from $42.5 \%$ to $45 \%$ for ADF.

Forage dry matter intake was related to their NDF percentage, while dry matter digestibility was related to ADF, especially lignin. Thus, ADF indicated the percentage of highly indigestible material in the feed. Conversely, low ADF rates meant higher energy and digestibility, whereas forages with low NDF have a higher consumption rate than those with high NDF contents. Since NDF percentages between 55\% and $60 \%$ of DM are negatively associated with 
intake, lower rates are desirable (Van Soest, 1994).

Both cultivars presented similar ruminal DM disappearance rates in the early hours of incubation (Figure 1). However, at $6 \mathrm{~h}$ after incubation, Stylosanthes guianensis cv. Mineirão presented a higher disappearance rate $(53.54 \%)$ and maintained such behavior until the end of the assay.

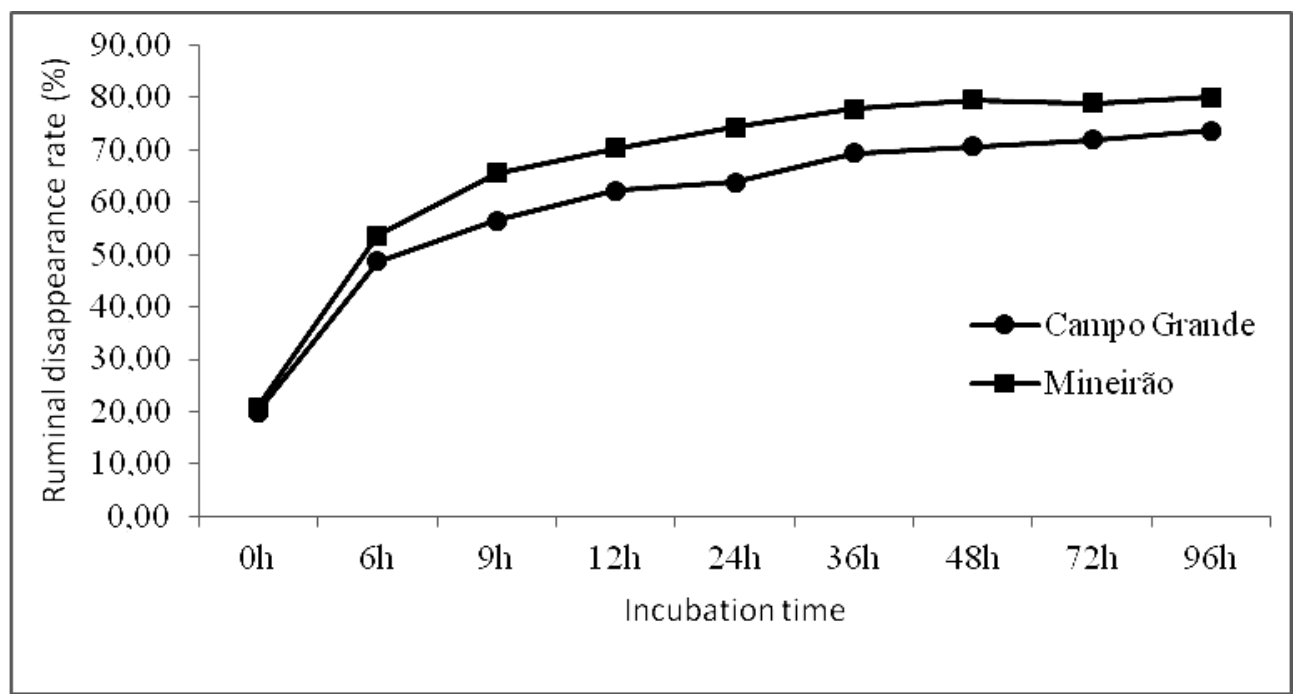

Figure 1. Average (\%) Dry Matter disappearance of cultivars Mineirão and Campo Grande, according to incubation time (hours).

Campo Grande's DM ruminal disappearance at the end of the incubation period (96 hours) was higher than $70 \%$, with increasing rate trend. Regarding cultivar Mineirão, the graph line indicated constant trend after 48 hours. Pires et al. (2006) evaluated alfalfa, oats, pigeon pea and leucaena and found a constant trend as from 36 incubation hours for the DM, with maximum disappearance at $83 \%$ for oats at 72 incubation hours, which is higher than that by foragers under analysis.

Initial cultivar Campo Grande NDF disappearance (Figure 2) was higher than that of cultivar Mineirão, with higher disappearance rates at all other times. Initial disappearance influenced potential degradability (PD) since it was the sum of initial disappearance and the potentially degradable insoluble portion.
Cultivar Mineirão showed higher ruminal disappearance ADF rates at all analyzed times (Figure 3) and thus indicated a fiber with better nutritional quality and probably with lower antinutritional substances levels, such as tannins.

After 48 hours, cultivar Mineirão ADF disappearance remained relatively constant, whereas in the case of cultivar Campo Grande the disappearance was irregular during the entire experimental period. Both forages showed high disappearance rate at time zero, highly unusual for the analyzed nutrients. It was probably due to lack of uniformity in the preparation of the samples, which influenced the nutrient's potential but not its effective degradability (Magalhães et al., 2005).

Mineirão stylo showed higher potential degradability (PD) for DM, NDF and ADF (Table 2). 


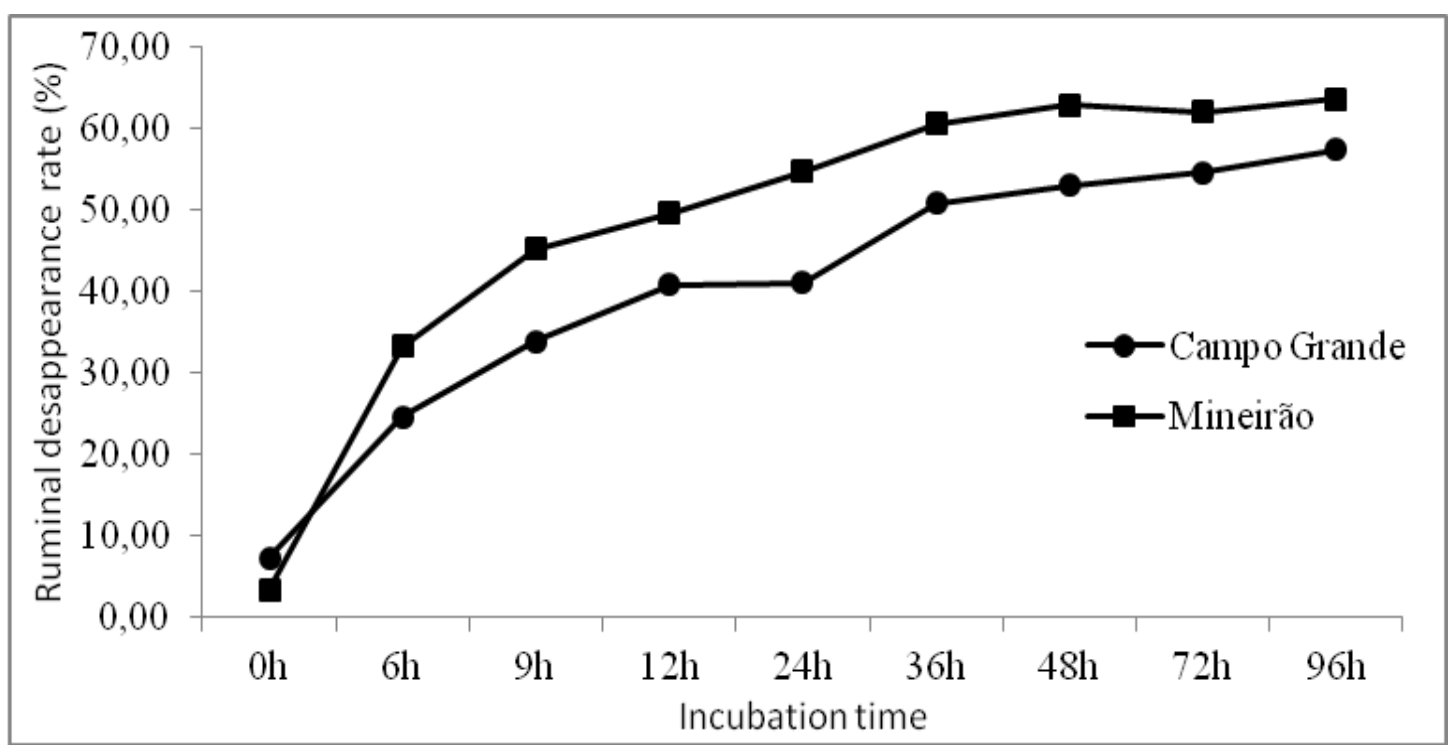

Figure 2. Average (\%) Neutral Detergent Fiber disappearance rate of cultivars Mineirão and Campo Grande, according to incubation time (hours).

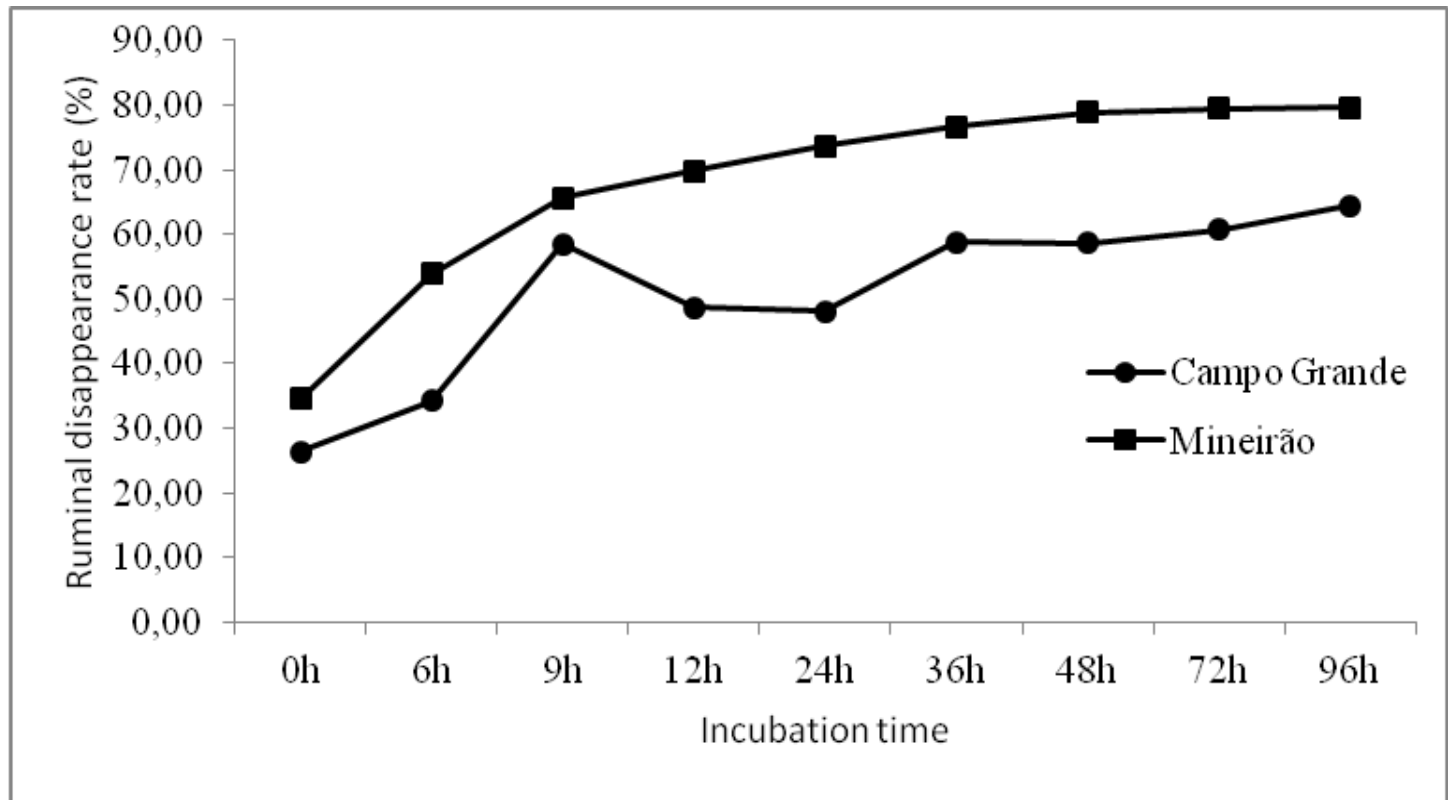

Figure 3. Average (\%) Acid Detergent Fiber disappearance rate of cultivars Mineirão and Campo Grande, according to incubation time (hours).

Table 2. Fractions A, B and C and potential degradability (PD) of dry matter (DM), neutral detergent fiber (NDF) and acid detergent fiber (ADF) of cultivars Mineirão (MS) and Campo Grande (CGS) stylo

\begin{tabular}{ccccccccc} 
& \multicolumn{2}{c}{ A $(\%)$} & \multicolumn{2}{c}{ B $(\%)$} & \multicolumn{2}{c}{ C $\left(\% \mathrm{~h}^{-1}\right)$} & \multicolumn{2}{c}{ PD $(\%)$} \\
\cline { 2 - 9 } & MS & CGS & MS & CGS & MS & CGS & MS & CGS \\
DM & 20.91 & 19.98 & 59.13 & 53.63 & $0.631 \mathrm{~A}$ & $0.463 \mathrm{~B}$ & $80.04 \mathrm{~A}$ & $73.61 \mathrm{~B}$ \\
NDF & 3.41 & 7.32 & 60.25 & 50.09 & $0.598 \mathrm{~A}$ & $0.407 \mathrm{~B}$ & $63.66 \mathrm{~A}$ & $57.41 \mathrm{~B}$ \\
ADF & 34.57 & 26.35 & 45.02 & 38.13 & $0.757 \mathrm{~A}$ & $0.291 \mathrm{~B}$ & $79.59 \mathrm{~A}$ & $64.48 \mathrm{~B}$ \\
\hline
\end{tabular}

${ }^{\mathrm{AB}}$ Values in same row, for the same analyzed fraction, followed by different letters are different according to the Scott-Knot test $(\mathrm{P}<0.05)$. 
In current research the cultivar Campo Grande PD was close to rates reported by Valarini and Possenti (2006), which ranged between $65.1 \%$ (Centrosema pubescens) and $75.9 \%$ (Macrotyloma axillare) for DM and between $46.3 \%$ (Centrosema pubescens) and $58.8 \%$ (Neonotonia wightii) for NDF.

Degradation rate (C fraction) was different for all analyzed nutrients, with the highest difference for $\mathrm{ADF}$. The $\mathrm{ADF}$ fraction was composed of cellulose and lignin and various amounts of ash and nitrogen compounds, while NDF is a portion of low degradation rate, commonly associated with physical limitation of food intake (Allen, 1996).

Lag time (Table 3 ) differed $(\mathrm{P}<0.05)$ only for the ADF portion. Cultivar Campo Grande presented a higher lag time than cultivar Mineirão, with only 1.54 hours. Lag Time indicates the time necessary for rumen microorganisms to colonize the food wrapped in nylon bags. The shorter lag time, the faster degradation starts. If lag time is too long, the presence of non-degraded food in rumen prevents the consumption of more food.

Cultivars Mineirão and Campo Grande showed satisfactory lag times. Veloso et al. (2006) reported lag times of 1.37, 5.72, 1.74, 3.31 and 1.76 hours for Leucaena leucocephala, Cajanus cajan, Neonotonia wightii, Boehmeria nivea and Manihot esculenta leaves and leaflets, respectively.

Cultivar Mineirão's effective degradability (ED) was higher $(\mathrm{P}<0.05)$ than that of cultivar Campo Grande at all passage rates and for all the analyzed portions.

The highest ED difference occurred for the ADF portion. At 5\% / hour passage rate cultivar Mineirão's ED was $76.81 \%$, while cultivar Campo Grande's ED was $58.89 \%$. Shorter cultivar Mineirão's ADF lag time (Table 3) contributed to its higher degradability.

Table 3. Lag time (LT) and effective degradability (ED) for three passage rates $(0.02,0.05$ and $0.08 / \mathrm{h})$ of dry matter (DM) neutral detergent fiber (NDF) and acid detergent fiber (ADF) for cultivars Mineirão (MS) and Campo Grande (CGS)

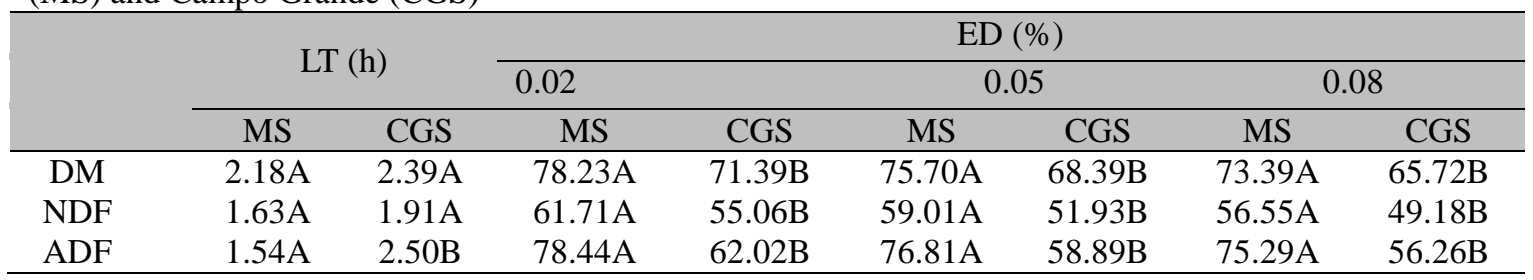

Values in the same line, for the same analyzed fraction, followed by different letters differ by the Scott-Knot test at $5 \%$ probability.

Comparing the effective DM degradability (EDMD) in the current study with other foragers, the cultivars Mineirão and Campo Grande presented a superior performance to that reported by Valarini and Possenti (2006) for Galactia striata, Centrosema pubescens, Macrotyloma axillare, Neonotonia wightii and Stylosanthes guianensis which EDMD was 52.2, 49.8, 64.0, 61.6 and $53.5 \%$, respectively at a 0.05 passage rate. Prado et al. (2004) registered Cynodon plectostachyrus EDMD at $23.1 \%$ and Veloso et al. (2006) reported $71.4 \%$ for $N$. wightii EDMD.

Effective dry matter degradability close to that in the current study was obtained by Pires et al. (2006) for Avena strigosa (68.4\%).
Regarding NDF, the ED at 0.05 passage rate ranged between $13.11 \%$ for pigeon pea (Cajanus cajan) (Carvalho et al., 2006) and 50.9\% for oats (A. strigosa) (Pires et al., 2006). Valarini and Possenti (2006) reported 34.3, 25.7, 37.5, 36.9 and $35.3 \%$ respectively for $G$. striata, $C$. pubescens, $M$. axillare, $N$. wightii and $S$. guianensis.

The minimum effective ADF degradability $(14.96 \%)$ occurred in pigeon pea, (Carvalho et al., 2006). Pires et al. (2006) reported $51.7 \%$ for A. strigosa; $41.9 \%$ for Medicago sativa; $41.2 \%$ for L. leucocephala; $42.0 \%$ for C. cajan. 


\section{CONCLUSIONS}

The two analyzed forages showed high potential and high effective DM, NDF and ADF degradability, and thus high nutritional rates. Cultivar Mineirão presented higher digestibility for dry matter and fibrous portion. The two forages showed low lag time. However, degradation rates revealed that cultivar Mineirão had better digestibility of fiber fraction than cultivar Campo Grande. This fact, associated to the great difference in lag time, suggested that cultivar Campo Grande had higher ADF phenol compound rates.

\section{REFERENCES}

AGUIAR, L.M.S.; MACHADO, R.B.; MARINHO FILHO, J. A Diversidade Biológica do Cerrado. In: AGUIAR, L.M.S.; CAMARGO, A.J.A. (Eds), Cerrado: ecologia e caracterização. Embrapa Informação Tecnológica, Brasília, 2004. p.17-41.

ALLEN, M.S. Physical constraints on voluntary intake of forages by ruminants. J. Anim. Sci., v.74, p.3063-3075, 1996.

ASSOCIATION Of Official Analytical Chemists - A.O.A.C. Official methods of analysis. 12.ed. Washington. D.C: AOAC INTERNATIONAL, 1975. 1094p.

BARCELLOS, A.O.; RAMOS, A.K.B.; VILELA, L. et al. Sustentabilidade da produção animal baseada em pastagens consorciadas e no emprego de leguminosas exclusivas, na forma de banco de proteína, nos trópicos brasileiros. Rev. Bras. Zootec., v.37, p.51-67, Suplemento Especial, 2008.

BARROS, A.M.; FALEIRO, F.G.; KARIA, C.T. et al. Variabilidade genética e ecológica de Stylosanthes macrocephala determinadas por RAPD e SIG. Pesq. Agropec. Bras., v.40, p.899909, 2005.

BRITO, R.M.; SAMPAIO, A.A.M.; FERNANDES, A.R.M. et al. Degradabilidade in situ e parâmetros ruminais em bovinos alimentados com dietas balanceadas para diferentes ganhos de peso e potenciais de fermentação microbiana. Rev. Bras. Zootec., v.36, p.1639-1650, 2007.

CARVALHO, G.G.P.; PIRES, A.J.V. Leguminosas tropicais herbáceas em associação com pastagens. Arch. Zootec., v.57, p.103-113, 2008.
CARVALHO, G.G.P.; PIRES, A.J.V.; VELOSO, C.M. et al. Degradabilidade ruminal do feno de alguns alimentos volumosos para ruminantes. Arq. Bras. Med. Vet. Zootec., v.58, p.575-580, 2006.

CULTIVO e uso do estilosantes Campo Grande. Comunicado Técnico, 105. Campo Grande: Embrapa-CNPGC, 2007. 11p.

KARIA, C.T.; ANDRADE, R.P.; FERNANDES, C.D. et al. Gênero Stylosanthes. In: FONSECA, D.M.; MARTUSCELLO, J.A. (Eds). Plantas Forrageiras. Viçosa: UFV, 2010. p.366-401.

MAGALHÃES, R.T.; GONÇALVES, L.C.; RODRIGUES, J.A.S. et al. Estimativa da degradabilidade ruminal de quatro genótipos de sorgo (Sorghum bicolor (L.) Moench) utilizando a técnica in situ. Acta Sci., Anim. Sci., v.27, p.483-490, 2005.

MCDONALD, I. A revised model for the estimation of protein degradability in the rumen. J. Agric. Sci., v.96, p.251-252, 1981.

MOURA, R.L.; NASCIMENTO, M.P.S.C.B.; RODRIGUES, M.M. et al. Razão folha/haste e composição bromatológica da rebrota de estilosantes Campo Grande em cinco idades de corte. Acta Sci., Anim. Sci., v.33, p.249-254, 2011.

MYERS, N.; MITTERMEIER, R.A.; MITTERMEIER, C.G. et al. Biodiversity hotspots for conservation priorities. Nature, v.403, p.853-858, 2000.

ORSKOV, E.R.; McDONALD, I. The estimation of protein degradability in the rumen from incubation measurements weighted according to rate passage. J. Agric. Sci., v.92, p.499-503, 1979.

PACIULLO, D.S.C.; AROEIRA, L.J.M.; ALVIM, M.J. et al. Características produtivas e qualitativas de pastagem de braquiária em monocultivo e consorciada com estilosantes. Pesq. Agropec. Bras., v.38, p.421-426, 2003.

PIRES, A.J.V.; REIS, R.A.; CARVALHO, G.G.P. et al. Degradabilidade ruminal da matéria seca, fração fibrosa e da proteína bruta de forrageiras. Pesq. Agropec. Bras., v.41, p.643-648, 2006.

PRADO, I.N.; MOREIRA, F.B.; ZEOULA, L.M. et al. Degradabilidade in situ da matéria seca, proteína bruta e fibra em detergente neutro de 
algumas gramíneas sob pastejo contínuo. Rev. Bras. Zootec., v.33, p.1332-1339, 2004.

ROBERTSON, J.B.; VAN SOEST, P.J. The detergent system of analysis and its application to human foods. In: JAMES, W.P.T.; THEANDER, O. (Eds.). The analysis of dietary fiber in food. New York: Marcel Dekker, 1981. p.123-158.

SANO, E.E.; ROSA, R.; BRITO, J.L.S. et al. Mapeamento semidetalhado do uso da terra do Bioma Cerrado. Pesq. Agropec. Bras., v.43, p.153-156, 2008.

SILVA, J.J.; SALIBA, E.O.S. Pastagens consorciadas: uma alternativa para sistemas extensivos e orgânicos. Vet. Zootec., v.14, p.8-18, 2007.

SILVEIRA, P.M.; BRAZ, A.J.B.P.; KLIEMANN, H.J. et al. Acumulação de Nutrientes no Limbo Foliar de Guandu e Estilosantes. Pesq. Agrop. Trop., v.35, p.133-138, 2005.
STATISTICAL analysis system - SAS. SAS/STAT user's guide. v.2, 4.ed. Cary, 1989. $846 \mathrm{p}$.

VALARINI, M.J.; POSSENTI, R.A. Research Note: Nutritive value of a range of tropical forage legumes. Trop. Grasslands, v.40, p.183187, 2006.

VAN SOEST, P.J. Nutrition ecology of the ruminant. 2.ed. Ithaca: Cornell University Press, 1994. $528 \mathrm{p}$.

VELOSO, C.M.; RODRIGUEZ, N.M.; CARVALHO, G.G.P. et al. Degradabilidade ruminal da matéria seca e da proteína bruta de folhas e folíolos de forrageiras tropicais. Rev. Bras. Zootec., v.35, p.613-617, 2006.

VERZIGNASSI, J.R.; FERNANDES, C.D. Estilosantes Campo Grande: situação atual e perspectivas. Empresa Brasileira de Pesquisa Agropecuária-Embrapa, Comunicado Técnico, 70, Campo Grande, 2002. 3p. 